\title{
Total testosterone and sex hormone-binding globulin as predictor markers of metabolic syndrome among obese people from Basrah
}

\begin{abstract}
Background: Metabolic syndrome (MetS) is an important public health target for disease prevention. Studies on MetS among obese people alone are few. In this study we aimed to see whether total testosterone (TT) and sex hormone-binding globulin (SHBG) have a role in the prediction of MetS in obese adult people from Basrah.

Methods: A cross-sectional study conducted during the period from October 2016 to the end of October 2017 in Faiha Specialized Diabetes, Endocrine, and Metabolism Center (FDEMC) in Basrah. Participants were obese adults referred to the Center from other hospitals, Primary Care Centers, and private clinics. The total enrolled patients in this study were 169 patients ( 89 women.52.66\% and 80 men.47.33\%). A short history and clinical examination were taken from each participant for age, gender, blood pressure, weight, height, waist circumference, blood pressure and body mass index (BMI). A fasting morning blood sample was taken for measurement of basal serum TT, serum SHBG, serum C-peptide, plasma insulin, plasma sugar and serum lipid profile.

Results: Both TT and SHBG were significantly lower in obese men with MetS in comparison with men without ( $P=0.0002$ and $P=0.003$ respectively). Mean TT in $\mathrm{ng} / \mathrm{dL}$ in obese men with MetS was $(250.08 \pm 96.07)$ vs. $(400.37 \pm 149.37)$ in obese men without. While mean SHBG in $\mathrm{nmoL} / \mathrm{L}$ in obese men with MetS was $(28.95 \pm 14.21)$ vs. $(42.49 \pm 24.11)$ in obese men without. In obese women, there was no significant different in SHBG levels when compared between those with MetS and without $(P=0.8)$. On univariate and multivariate analysis for obese men, both TT and SHBG remained significantly and independently lower in obese men with MetS, for TT (OR 6.4 CI (-321.9- -157.9) $P<0.00001$ ), and for SHBG (OR 1.39, CI (-49.3- -19.6) $P=0.00001)$. In men with no MetS, both TT and SHBG were significantly higher in men with severe in insulin resistance (IR) when compared with normal and moderate IR, $(P=0.01, P=0.01$ respectively). Mean TT was $(396.09 \pm 19.3)$ in men with severe IR as compared with $(311.4 \pm 26)$ and $(274.6 \pm 23.9)$ in normal and moderate IR respectively. Mean SHBG in men with severe IR was (41.1 \pm 3.5$)$ as compared with (28.2 \pm 4.7$)$ and $(31.9 \pm 4.3)$ in normal and moderate IR respectively.
\end{abstract}

Conclusion: Both TT and SHBG were significantly and independently lower in obese men with MetS than those with no MetS, but not in obese women with MetS. The effect of MetS overcomes the effect of IR in decreasing the level of both TT and SHBG among obese men in the presence of MetS.

Keywords: metabolic syndrome, obesity, total testosterone, sex hormone-binding globulin
Volume 6 Issue I - 2018

\author{
Muayad Baheer Kadhim,' Abdul Ameer A \\ Abdul Hameed, ${ }^{2}$ Abbas Ali Mansour ${ }^{3}$ \\ 'Missan Directorate of Health, Iraq \\ ${ }^{2}$ Cardiology Division, Department of Medicine, Basrah College \\ of Medicine, Iraq \\ ${ }^{3}$ Diabetes, Endocrine, and Metabolism Division, Department of \\ Medicine, Basrah College of Medicine, Iraq
}

\begin{abstract}
Correspondence: Abbas Ali Mansour, MD, FRCP, FACE, Professor of Medicine, Consultant Endocrinologist, Faiha Specialized Diabetes, Endocrine and Metabolism Center, FDEMC, Chair Diabetes, Endocrine, and Metabolism Division, Department of Medicine, Basrah College of Medicine, Hattin post office, P O Box, I42, Basrah 61013, Iraq, Tel 00964780I403706,Email aambaam@gmail.com
\end{abstract}

Received: December 09, 2017 | Published: February I, 2018
Abbreviations: MetS, metabolic syndrome; TT, total testosterone; FDEMC, faiha specialized diabetes, endocrine, and metabolism center; HOMA, homeostasis model assessment; ROC, receiver operating characteristic; $\mathrm{SBP}$, systolic blood pressure; DBP, diastolic blood pressure.

\section{Introduction}

Studies on metabolic syndrome (MetS) among obese people alone are few. ${ }^{1,2}$ Most of the studies using comparison for the prevalence of MetS among non-obese people. ${ }^{3,4}$ Low levels of serum total testosterone (TT) and sex hormone-binding globulin (SHBG) are associated with an increase in the incidence of development of MetS. ${ }^{5}$. The insulin resistance syndrome is significantly associated with increased risk of T2DM and CVD. ${ }^{6}$

Testosterone itself may have a central or preventive role in the pathogenesis of T2DM and the MetS by increasing skeletal muscle mass and lowering abdominal obesity and non-esterified fatty acids, and thus may improve the sensitivity of insulin. ${ }^{7}$ This study aimed to see whether TT and SHBG have a role in the prediction of MetS among obese adult people from Basrah.

\section{Patients and methods}

\section{Setting and participants}

This cross-sectional study was conducted during the period from October 2016 to October 2017 in Faiha Specialized Diabetes, Endocrine, and Metabolism Centre (FDEMC). Participants were obese adults referred to the Center from other hospitals, primary health care Centers, and private clinics. The total enrolled patients in this study were 169 patients ( 89 women. $52.66 \%$ and 80 men. $47.33 \%$ ). All subjects provided with the written informed consent and the ethical committee of the Basrah College of Medicine approved the research protocol. 


\section{Inclusion criteria}

Obese adult's people with body mass index (BMI) $\geq 30 \mathrm{~kg} / \mathrm{m}^{2}$.

\section{Exclusion criteria}

a. History of hypogonadism.

b. Patients on testosterone replacement therapy, androgen deprivation therapy, contraceptive pills or hormone replacement therapy.

c. Patients with a history of chronic liver disease and/ or chronic kidney disease.

\section{Clinical data}

From each participant, history taking and clinical examination was done for assessment of inclusions and exclusions criteria, and clinical data collection in form of blood pressure, weight, height, and waist circumference. Weight and height were measured using light clothes. BMI was calculated as weight $(\mathrm{kg}) /$ height $(\mathrm{m})^{2}$. Waist circumference was measured as the circumference of the abdomen at its narrowest point in midway point between the lower costal border ( $\left.10^{\text {th }} \mathrm{rib}\right)$ and the top of the iliac crest, perpendicular to the long axis of the trunk.

\section{Biochemical data}

Instructions were given to the patients to avoid any drug that may interfere with laboratory assay and to come next day early morning at 8:00a.m. after at least 8-12hours fasting for sample collection. Ten $\mathrm{ml}$ of the blood sample was obtained and collected in tubes containing clot activator. The serum was separated by using centrifuge 3000r.p.m. and stored frozen at -20degree centigrade until analysis. The Fully automated chemiluminescence immunoassay kits Cobas e411 analyzer series/ Roche Diagnostics, Germany, was used for the assessment of TT (reference value.adult men from 300 to $1200 \mathrm{ng} / \mathrm{dL}$ [10.40 to $41.60 \mathrm{nmol} / \mathrm{L}$ ), adult women (reference value 20 to $75 \mathrm{ng} / \mathrm{dL} .0 .69$ to $2.60 \mathrm{nmol} / \mathrm{L}$ ), C-peptide(reference value from 0.9 to $4.3 \mathrm{ng} / \mathrm{mL} .0 .29$ to $1.43 \mathrm{nmol} / \mathrm{L}$ ), insulin level (reference value 2.6 to $24.9 \mu \mathrm{U} / \mathrm{mL} .18 .05$ to $172.9 \mathrm{pmol} / \mathrm{L}$ ) and SHBG (reference value for male 10 to $60 \mathrm{nmol} /$ $\mathrm{mL}$ and for women 20 to $130 \mathrm{nmoL} / \mathrm{mL}$ ). C-peptide and glucose was measured within 7hours of blood sampling to avoid loss of stability. ${ }^{8}$ Glucose and lipid profile was measured by cobas c311analyzer. MetS diagnosis was according to the 2005 IDF criteria. ${ }^{9}$

\section{HOMA-IR calculation}

Among individuals with normal glucose regulation, the IR was assessed from FPG and insulin concentrations with the homeostasis model assessment (HOMA) equation: HOMA = fasting plasma glucose $(\mathrm{mg} / \mathrm{dL}) \times$ fasting plasma insulin $(\mu \mathrm{U} / \mathrm{mL}) / 405$ which are superior to insulin measurement alone. ${ }^{10}$

\section{Statistical analysis}

All data were computerized and analyzed using Statistical Package for Social Sciences (SPSS), (version 23.0). Continuous variables were summarized as the mean \pm standard deviation (SD), and categorical variables were summarized as percentages. The Multivariate and univariate analysis were used to study the effect of multiple factors in form of age, MetS, and HOMA-IR on both TT and SHBG in men, and on SHBG in women. Receiver operating characteristic (ROC) was plotted to identify the sensitivity and specificity of the level of TT and SHBG with MetS. For all the tests were has been done, a $P$ value of $<0.05$ was considered statistically significant.

\section{Results}

In women, as shown in Table 1, the mean age was $43.7 \pm 9.5$ years, BMI $38.5 \pm 7.3 \mathrm{~kg} / \mathrm{cm}^{2}$. The mean systolic blood pressure (SBP), diastolic blood pressure (DBP) and waist circumference (WC) were $133.9 \pm 17.5 \mathrm{mmHg}, 83.3 \pm 9.4 \mathrm{mmHg}$, and $120.3 \pm 12.20 \mathrm{~cm}$ respectively. MetS was prevalent in $59 / 89$ patients $(66.3 \%)$. Both T2DM and hypertension (HTN) were seen in 45/89 (50.6 \%) and 28/89 (31.5 $\%$ respectively. Mean FPG, insulin, C-peptide, high density lipoprotein cholesterol (HDL-C), triglyceride (TG), TT, SHBG were $181 \pm 102.5 \mathrm{mg} / \mathrm{dl}, 17.9 \pm 17.25 \mu \mathrm{u} / \mathrm{mL}, 4.1 \pm 3 \mathrm{ng} / \mathrm{mL}, 47.2 \pm 12.5 \mathrm{mg} /$ $\mathrm{dl}, \quad 209.3 \pm 163.4 \mathrm{mg} / \mathrm{dl}, \quad 19.26 \pm 16.3 \mathrm{ng} / \mathrm{dl}$, and $41.37 \pm 22.3 \mathrm{nmoL} / \mathrm{L}$ respectively. The mean HOMA-IR was $8.4 \pm 10.6$, with $25(29.2 \%)$ had normal, 17 (20.2\%) had moderate, and 42 (50\%) had severe HOMAIR.

In men, the mean age was $44.5 \pm 11.3 y$ years, mean BMI was $35.2 \pm 7 \mathrm{~kg} / \mathrm{cm}^{2}$. Mean SBP, DBP and WC were $138.8 \pm 20.5 \mathrm{mmHg}$, $87.9 \pm 10 \mathrm{mmHg}, 115.5 \pm 12.7 \mathrm{~cm}$ respectively. The prevalence of MetS was 59/80(73.8\%) patients, while T2DM and HTN were seen in $59 / 80(73.8 \%)$ and $30 / 80(37.5 \%)$ respectively. The mean FPG, insulin, C-peptide, HDL-C, TG, TT, SHBG were $182.4 \pm 91 \mathrm{mg} / \mathrm{dL}$, $23.2 \pm 27.5 \mu \mathrm{u} / \mathrm{mL}, 4 \pm 3.3 \mathrm{ng} / \mathrm{mL}, 38.4 \pm 10.4 \mathrm{mg} / \mathrm{dL}, 242.9 \pm 182.3 \mathrm{mg} /$ $\mathrm{dL}, 290.5 \pm 130.3 \mathrm{ng} / \mathrm{dL}$ and $32.6 \pm 22.3 \mathrm{nmoL} / \mathrm{L}$ respectively. The mean HOMA-IR was $9.2 \pm 9.5,12(16.7 \%)$ had normal, $16(22.2 \%)$ moderate, and $44(61.1 \%)$ had severe HOMA-IR.

It was found that in this study that TT level was significantly lower in obese men with MetS than those without MetS $(P$ value $=0.0002)$. Among male group with MetS the mean TT was $(250.08 \pm 96.07 \mathrm{ng} /$ $\mathrm{dl}, \quad 8.67 \pm 3.33 \mathrm{nmoL} / \mathrm{L})$, while in those without MetS it was $(400.37 \pm 149.37 \mathrm{ng} / \mathrm{dl}, 13.89 \pm 5.17 \mathrm{nmol} / \mathrm{L})$, as shown in Table 2 .

SHBG affected in a way similar to that of TT, obese men with MetS had a significantly lower levels of SHBG when compared to those without MetS, $(P$ value $=0.003)$, Table 2 . The means SHBG were $(28.95 \pm 14.21 \mathrm{nmoL} / \mathrm{L})$ and $(42.49 \pm 24.1 \mathrm{nmoL} / \mathrm{L})$ in men with MetS and without respectively. In women, there was no significant difference in SHBG between those with MetS and without. ( $P$ value $=0.8$ ), Tables $2 \& 3$.

Obese women with MetS was tended to be older than those without, (46.03years \pm 8.2 years) versus (39.10years \pm 10.42 years) respectively ( $\mathrm{P}$ value $=0.001)$, however, age did not vary significantly in men group ( $p$-value $=0.07$ ). BMI and IR had no significant different when correlated with MetS neither in men nor women, Tables $2 \& 3$.

Assessment of the effect of MetS, IR, and age on SHBG in obese women using univariate analysis showed that these factors had no statistically significant effect on SHBG as shown in Table 4 . In obese men, on univariate analysis (Table $4 \&$ Figure 1), TT was significantly lower in those with MetS independently of the presence of IR than those without MetS (MetS OR 6.4 CI (-321.9- -157.9) P<.00001). In men with no MetS, TT was significantly higher in men with severe IR when compared with normal IR (OR 1.4, CI (-319-34.1), $\mathrm{P}=0.016)$ and moderate IR (OR 2.13 CI (-324-38.2) $\mathrm{P}=0.014)$. Mean TT was $(396.09 \pm 19.3)$ in men with severe IR as compared with $(311.4 \pm 26)$ and (274.6 \pm 23.9$)$ in normal and moderate IR respectively. The effect of MetS is higher than the IR in decreasing the level of TT.

SHBG had been affected in a similar manner as shown in (Table 4 \& Figure 2). SHBG was significantly lower in men with MetS independently of the presence of IR than patients with no MetS. (MetS 
OR 1.39, CI (-49.3- -19.6) $P=0.00001)$. On the other hand in men without MetS, SHBG was significantly higher in men with severe IR when compared with normal IR(OR 1.26 CI(-60.2-(-8.3), $P=0.01)$. Mean SHBG in men with severe IR was $(41.1 \pm 3.5)$ as compared with
$(28.2 \pm 4.7)$ and $(31.9 \pm 4.3)$ in normal and moderate IR respectively. The effect of MetS is higher than the IR in decreasing the level of SHBG. These findings indicate that MetS reduced both TT and SHBG independently in men patients.

Table I General characteristics of the study population

\begin{tabular}{|c|c|c|}
\hline & Women Mean \pm SD* or $\mathbf{N} * *$ (\%) & Men Mean \pm SD or $\mathbf{N}(\%)$ \\
\hline & $89(52.66 \%)$ & $80(47.33 \%)$ \\
\hline Age(Years) & $43.7 \pm 9.5$ & $44.5 \pm(1.3)$ \\
\hline $\mathrm{BMI} \Omega\left(\mathrm{kg} / \mathrm{m}^{2}\right)$ & $38.5 \pm 7.3$ & $35.2 \pm 7.0)$ \\
\hline $\mathrm{SBP} ¥(\mathrm{mmHg})$ & $133.9 \pm 17.5$ & | $38.8(20.5)$ \\
\hline DBPா $(\mathrm{mmHg})$ & $83.3 \pm 9.4$ & $87.9(10)$ \\
\hline $\mathrm{WC}+(\mathrm{cm})$ & $120.3 \pm 15.20$ & $115.5(12.7)$ \\
\hline T2DMa N(\%) & $45(50.6 \%)$ & $59(73.8 \%)$ \\
\hline HTNC N(\%) & $28(31.5 \%)$ & $30(37.5 \%)$ \\
\hline MetS $\diamond N(\%)$ & $59(66.3 \%)$ & $59(73.8 \%)$ \\
\hline Fasting plasma glucose $(\mathrm{mg} / \mathrm{dL})$ & $181.5(10.08 \mathrm{mmol} / \mathrm{L}) \pm 102.5(5.69 \mathrm{mmoL} / \mathrm{L})$ & $182.4(10.13 \mathrm{mmoL} / \mathrm{L}) \pm 91(5.05 \mathrm{mmoL} / \mathrm{L})$ \\
\hline Insulin $(\mu \mathrm{u} / \mathrm{mL})$ & $17.9(\mid 24.30 \mathrm{pmoL} / \mathrm{L}) \pm 17.25(\mid 19.79 \mathrm{pmoL} / \mathrm{L})$ & $23.2(161.11 \mathrm{pmoL} / \mathrm{L}) \pm 27.5(190.97 \mathrm{pmoL} / \mathrm{L})$ \\
\hline C-peptide(ng/mL) & $4.1(1.36 \mathrm{nmoL} / \mathrm{L}) \pm 3(0.99 \mathrm{nmoL} / \mathrm{L})$ & $4(1.33 \mathrm{nmoL} / \mathrm{L}) \pm 3.3(1.09 \mathrm{nmoL} / \mathrm{L})$ \\
\hline $\mathrm{HDL}-\mathrm{C} \beta(\mathrm{mg} / \mathrm{dL})$ & $47.2(1.22 \mathrm{mmoL} / \mathrm{L}) \pm 12.5(0.32 \mathrm{mmoL} / \mathrm{L})$ & $38.4(0.99 \mathrm{mmoL} / \mathrm{L}) \pm 10.4(0.26 \mathrm{mmoL} / \mathrm{L})$ \\
\hline $\mathrm{TG} \Psi(\mathrm{mg} / \mathrm{dL})$ & $209.3(2.37 \mathrm{mmoL} / \mathrm{L}) \pm 163.4(1.84 \mathrm{mmoL} / \mathrm{L})$ & $242.9(2.74 \mathrm{mmoL} / \mathrm{L}) \pm 182.3(2.05 \mathrm{mmoL} / \mathrm{L})$ \\
\hline TTßng/dL & $19.26(0.66 \mathrm{nmoL} / \mathrm{L}) \pm 16.3(0.56 \mathrm{nmoL} / \mathrm{L})$ & $\begin{array}{l}290.5(\mid 0.08 \mathrm{nmoL} / \mathrm{L}) \pm \mid 30.3 \\
(4.52 \mathrm{nmoL} / \mathrm{L})\end{array}$ \\
\hline $\operatorname{SHBG} \infty(\mathrm{nmol} / \mathrm{L})$ & $41.37 \pm 22.3$ & $32.6 \pm 18.3$ \\
\hline \multirow[t]{2}{*}{ HOMA-IR $\Delta$} & $8.4 \pm 10.6$ & $9.2 \pm 9.5$ \\
\hline & Normal25 (29.2\%) & Normal I2(16.7\%) \\
\hline \multirow[t]{2}{*}{ N (\%) } & ModerateI7 (20.2\%) & ModerateI6(22.2\%) \\
\hline & Severe42 (50\%) & Severe44(61.1\%) \\
\hline \multicolumn{3}{|c|}{ 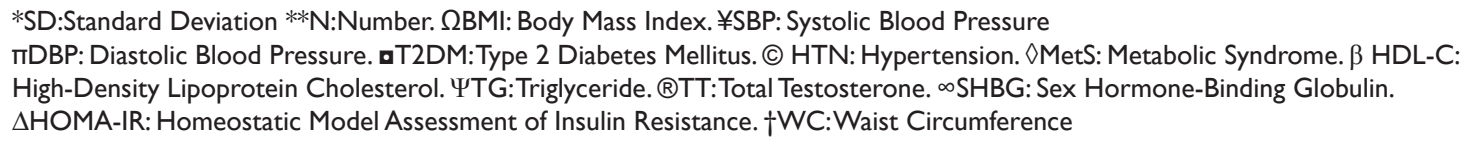 } \\
\hline
\end{tabular}

Table 2 Comparison of TT, SHBG, age, BMI and IR among obese patients with MetS and obese patients with no MetS in men

\begin{tabular}{|c|c|c|c|}
\hline Variable & MetS & Non-MetS & P Value \\
\hline $\begin{array}{l}\text { Age (Years) } \\
\text { Mean } \pm \text { SD }\end{array}$ & $46.10 \pm 10.36$ & $40.24 \pm 13.23$ & 0.07 \\
\hline $\begin{array}{l}\text { BMI }\left(\mathrm{kg} / \mathrm{m}^{2}\right) \\
\text { Mean } \pm \text { SD }\end{array}$ & $35.76 \pm 7.13$ & $33.65 \pm 6.66$ & 0.2 \\
\hline $\begin{array}{l}\mathrm{TT}(\mathrm{ng} / \mathrm{dL}) \\
\text { Mean } \pm \text { SD }\end{array}$ & $\begin{array}{l}250.08(8.67 \mathrm{nmoL} / \mathrm{L}) \pm 96.07 \\
(3.33 \mathrm{nmoL} / \mathrm{L})\end{array}$ & $\begin{array}{l}400.37(13.89 \mathrm{nmoL} / \mathrm{L}) \pm \mid 49.13(5.17 \\
\mathrm{nmoL} / \mathrm{L})\end{array}$ & 0.0002 \\
\hline $\begin{array}{l}\text { SHGB }(\mathrm{nmoL} / \mathrm{L}) \\
\text { Mean } \pm \mathrm{SD}\end{array}$ & $28.95 \pm \mid 4.21$ & $42.49 \pm 24.11$ & 0.003 \\
\hline $\begin{array}{l}\text { HOMA-IR } \\
\text { Mean } \pm S D\end{array}$ & $9.02 \pm 7.78$ & $9.82 \pm 13.36$ & 0.8 \\
\hline
\end{tabular}

Citation: Kadhim MB, Hameed AAA, Mansour AA. Total testosterone and sex hormone-binding globulin as predictor markers of metabolic syndrome among obese people from Basrah. Endocrinol Metab Int J. 20I8;6(I):42-48. DOI: 10.15406/emii.2018.06.00I53 
Table 3 Comparison of TT, SHBG, age, BMI and IR among obese patients with MetS and obese patients with no MetS in women

\begin{tabular}{llll}
\hline Variable & MetS & Non-MetS & P Value \\
\hline $\begin{array}{l}\text { Age (Years) } \\
\text { Mean } \pm S D\end{array}$ & $46.03 \pm 8.2$ & $39.10 \pm 10.42$ & 0.001 \\
$\begin{array}{l}\text { BMI }(\mathrm{kg} / \mathrm{m} 2) \\
\text { Mean } \pm \text { SD }\end{array}$ & $37.68 \pm 7.21$ & $40.34 \pm 7.43$ & 0.1 \\
$\begin{array}{l}\text { SHGB(nmoL/L) } \\
\text { Mean } \pm S D\end{array}$ & $41.0 \pm 22.59$ & $42.13 \pm 22.29$ & 0.8 \\
HOMA-IR Mean $\pm S D$ & $9.82 \pm 10.58$ & $5.72 \pm 10.34$ & 0.09
\end{tabular}

Table 4 Correlation of TT and SHBG with MetS by adjustment with age and IR by using univariate analysis in men and women patients

\begin{tabular}{|c|c|c|c|c|c|c|}
\hline Dependent Variable & Factors & Mean & Std. Error & OR & P Value & $95 \% \mathrm{CI}$ \\
\hline \multicolumn{7}{|l|}{ Men } \\
\hline & MetS & 248.677 & 15.944 & \multirow{2}{*}{6.4} & \multirow{2}{*}{$<0.00001$} & \multirow{2}{*}{$-321.9-(-157.9)$} \\
\hline & Non MetS & 406.072 & 21.636 & & & \\
\hline & Age $<45$ years & 321.343 & 19.345 & \multirow{2}{*}{0.03} & \multirow{2}{*}{0.9} & \multirow{2}{*}{$-146-139.5$} \\
\hline \multirow[t]{7}{*}{$\mathrm{TT}(\mathrm{ng} / \mathrm{dL})$} & Age $\geq 45$ years & 333.406 & 18.657 & & & \\
\hline & HOMA-IR & 311.425 & 26.043 & \multirow{3}{*}{$\begin{array}{l}1.4 \\
2.13\end{array}$} & \multirow{3}{*}{$\begin{array}{l}0.016 \\
0.014\end{array}$} & \multirow{3}{*}{$\begin{array}{l}-319.1-34.1 \\
-324-38.2\end{array}$} \\
\hline & $\begin{array}{l}\text { Normal } \\
\text { Moderate }\end{array}$ & 274.608 & 23.969 & & & \\
\hline & Severe & 396.090 & 19.301 & & & \\
\hline & MetS & 26.822 & 2.892 & \multirow{2}{*}{1.39} & \multirow{2}{*}{0.00001} & \multirow{2}{*}{$-49.3-(-19.6)$} \\
\hline & Non MetS & 40.724 & 3.924 & & & \\
\hline & Age $<45$ years & 30.894 & 3.508 & \multirow{2}{*}{2.5} & \multirow{2}{*}{0.09} & \multirow{2}{*}{$-48.1-3.7$} \\
\hline \multirow[t]{4}{*}{ SHBG(nmoL/L) } & Age $\geq 45$ years & 36.653 & 3.384 & & & \\
\hline & HOMA-IR & 28.283 & 4.723 & \multirow{3}{*}{$\begin{array}{l}1.26 \\
3.7\end{array}$} & \multirow{3}{*}{$\begin{array}{l}0.01 \\
0.069\end{array}$} & \multirow{3}{*}{$\begin{array}{l}-60.2-(-8.3) \\
-49.9-1.9\end{array}$} \\
\hline & Moderate & 31.937 & 4.347 & & & \\
\hline & Severe & 41.100 & 3.500 & & & \\
\hline \multicolumn{7}{|l|}{ Women } \\
\hline \multirow{8}{*}{ SHBG(nmoL/L) } & MetS & 43.8 & 3.3 & \multirow{2}{*}{3.4} & \multirow{2}{*}{0.1} & \multirow{2}{*}{$-43.3-4.3$} \\
\hline & Non MetS & 45 & 4.6 & & & \\
\hline & Age $<45$ years & 42.1 & 3.7 & \multirow{2}{*}{8.4} & \multirow{2}{*}{0.7} & \multirow{2}{*}{$-53.4-2.3$} \\
\hline & Age $\geq 45$ years & 46.7 & 4.3 & & & \\
\hline & HOMA-IR & 45.2 & 5.2 & \multirow{4}{*}{$\begin{array}{l}4.8 \\
2.5\end{array}$} & \multirow{4}{*}{$\begin{array}{l}0.2 \\
0.2\end{array}$} & \multirow{4}{*}{$\begin{array}{l}-15-59 \\
-52.8-13.1\end{array}$} \\
\hline & Normal & & & & & \\
\hline & derate & 37.9 & 5.5 & & & \\
\hline & Severe & 41 & 3.9 & & & \\
\hline
\end{tabular}

On multivariate analysis (Table 5), with both TT and SHBG used as dependent variables in men. TT was significantly decreased in patients with MetS $(P<0.00001)$, and significantly increased with increased IR $(\mathrm{P}=0.001)$. The effect of IR in increasing TT was mainly in the absence of MetS, $(P=0.0003)$. Similar finding was observed on SHBG, which was significantly decreased in patients with MetS $(P=0.006)$, and it was higher in men with severe IR especially in absence of MetS but with no statistical significance on multivariate analysis. While the age of the patients failed to have a significant effect on TT and SHBG. These findings indicate that both TT and SHBG decreased significantly and independent of each other in patients with MetS.

In men, TT and MetS demonstrated an ROC curve with good accuracy (area under the curve $\mathrm{AUC}=0.831$, Std. error $=0.058$, $P=0.000008$, 95\%CI $(0.7-0.9)$ as seen in Figure 3. TT cutoff of $237.5 \mathrm{ng} / \mathrm{dl}(8.23 \mathrm{nmol} / \mathrm{L})$ or less had $47.4 \%$ sensitivity and $95.2 \%$ 
specificity, cutoff $404,6 \mathrm{ng} / \mathrm{dl}(14.02 \mathrm{nmol} / \mathrm{L})$ or less had $94.7 \%$ sensitivity and $43 \%$ specificity, and cutoff of $344 \mathrm{ng} / \mathrm{dl}(11.92 \mathrm{nmol} / \mathrm{L})$ or less had $87.7 \%$ sensitivity and $72 \%$ specificity for MetS.

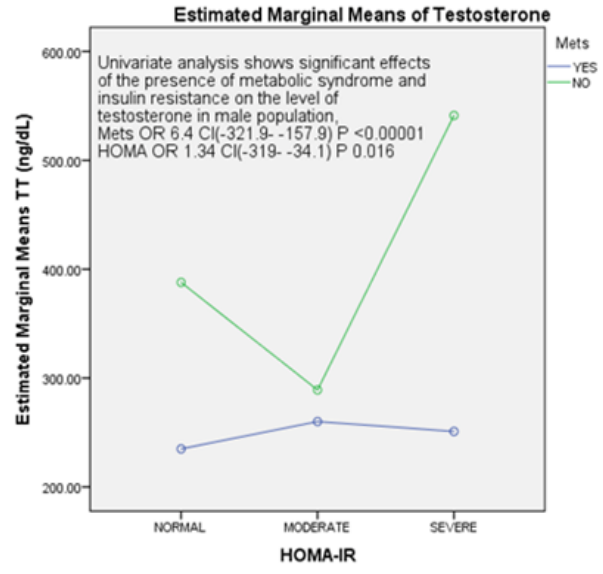

Figure I Correlation of TT with MetS and HOMA-IR in men patients.

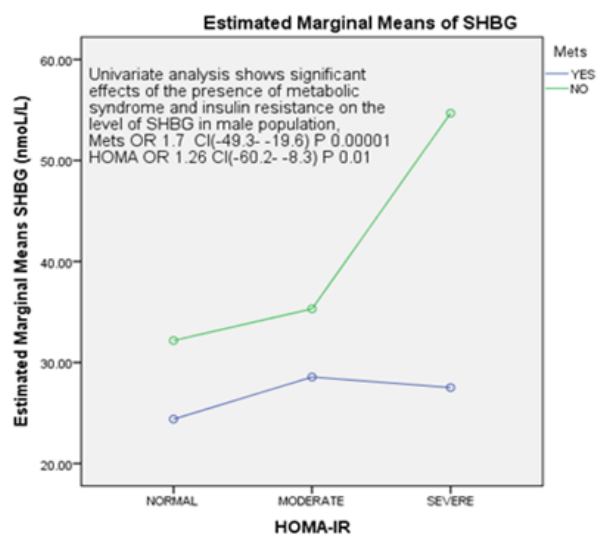

Figure 2 Correlation of SHBG with MetS and HOMA-IR in men patients.

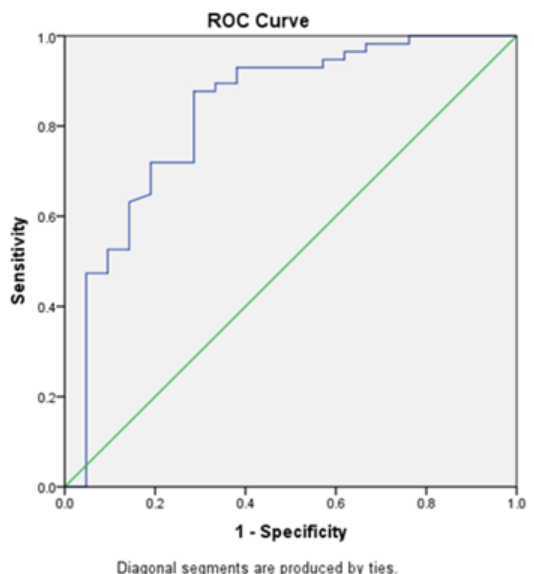

Figure 3 ROC Curve for the correlation of the low TT with the MetS in the men.

On the other hand SHBG and MetS demonstrated an ROC curve with poor accuracy (area under the curve $\mathrm{AUC}=0.693$, Std. error $=$ $0.07, \mathrm{P}=0.01,95 \% \mathrm{CI}(0.5-0.8)$ as shown in Figure 4 . A SHBG cutoff of $20.8 \mathrm{nmoL} / 1$ or less had $36.8 \%$ sensitivity and $86 \%$ specificity, cutoff $47.7 \mathrm{nmoL} / 1$ or less had $91 \%$ sensitivity and $29 \%$ specificity, and cutoff of $36.1 \mathrm{nmoL} / 1$ or less had $72 \%$ sensitivity and $67 \%$ specificity for MetS.

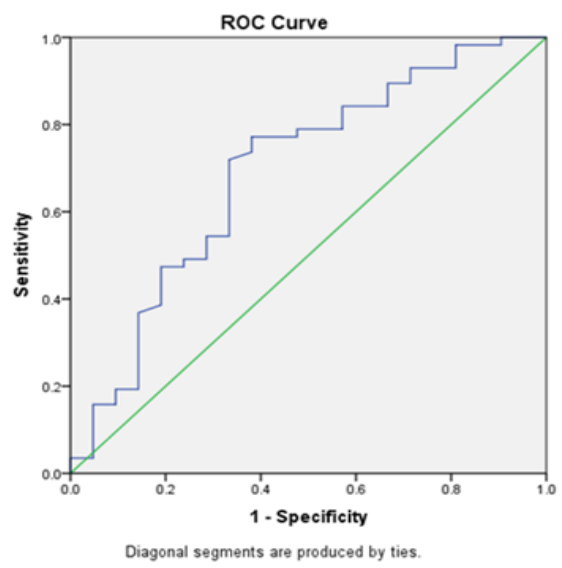

Figure 4 ROC Curve for the correlation of the low SHBG with the MetS in men.

Table 5 Correlation of TT and SHBG with MetS by adjustment with age and IR by using multivariate analysis in male patients

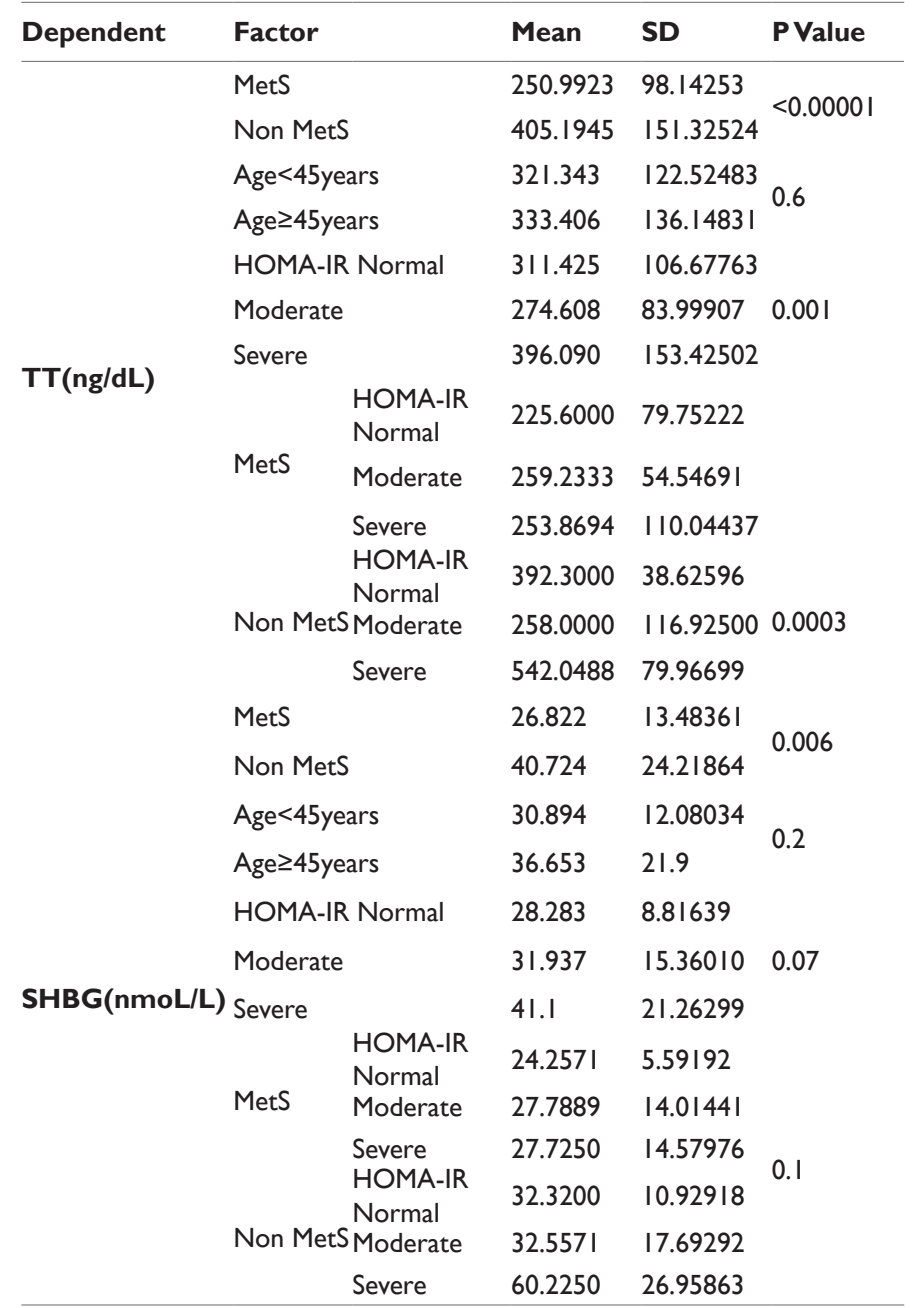




\section{Discussion}

The primary outcome results in our study were that in obese men, the TT in the presence of MetS was significantly lower than those obese men without the MetS and this compatible with Tanabe et al., study which concluded that only TT predicts MetS among middle aged Japanese men. ${ }^{11}$ In another study was done in Korea, they found that MetS has negative effect on the level of both TT and SHBG. ${ }^{12}$ consequently Laaksoneen et al., found that low level of TT and SHBG predict MetS and T2DM in middle age men. ${ }^{13}$

Why are these finding? It seems to be that an excess adipose tissue leads to the conversion of testosterone to estradiol which may result in secondary hypogonadism. ${ }^{14}$

Previous studies found that inflammatory cytokines may have a direct effect on the pituitary gland to decrease LH secretion, and a direct effect on secretion of testosterone from the Leydig cell (these two factors will reduce TT). ${ }^{15,16}$

There is dysregulation hypothalamic pituitary adrenal axis due to increased glucocorticoid production among obese patients and subsequent hypoandrogenism in men. ${ }^{17}$ Additional evidence that low TT which caused by androgen deprivation treatment in patients with prostate cancer may lead to increases the risk of MetS as seen in Basaria et al., study. ${ }^{18}$ For the first time had been found that testosterone replacement therapy improves insulin sensitivity and control of glucose in euglycemic clamp studies for men with obesity while reducing central adiposity. ${ }^{7}$. Two studies in women revealed that TT was not associated with the incidence of MetS. A longitudinal study of Menopause and the metabolic syndrome concluded that both high TT and low SHBG can predict MetS only in women during early menopause..$^{19}$ Additionally, another cohort study found that there is an association between TT in women and increase the risk of both IR and T2DM, but not MetS. ${ }^{20}$ Another impressive finding of this study is that SHBG was significantly lower in men with MetS than those without, which is similar result also seen in other studies. ${ }^{12,13}$ In a crosssectional study by Haring et al. ${ }^{21}$ they found that low SHBG correlate with MetS independent of TT level, a finding comparable to this study. Additionally in another study in China, found that low SHBG level associated with MetS both in adults and older population. ${ }^{22}$

The low SHBG in patients with MetS could be explained on the following hypothesis. Obesity associated with hyperinsulinism which suppresses SHBG synthesis and secretion by the liver. ${ }^{23}$ Additional evidence supporting the role of hyperinsulinism is the study of Pasquali et al. ${ }^{24}$ which notes a significant elevation in levels of SHBG happened after an acute decrease of insulin levels in obese men by treatment with diazoxide for one week and simultaneously, it increases TT production. However, in our study, we found that both TT and SHBG significantly increased with increase insulin level and severity of IR in men with no MetS only. While the study of Pasquali et al. ${ }^{24}$ has neglected the presence of MetS in the sample.

In this study, SHBG was not statistically significantly lower in obese women with MetS than those obese women with no MetS (low normal in both groups). This was agreed with the finding of a prospective cohort study in Spain which found that SHBG level was higher in women than that in men and it may have a protective function. Furthermore, SHBG does not affected by the presence of MetS in women. ${ }^{20}$ In study of Azrad et al. ${ }^{25}$ they found that intraabdominal adipose tissue in healthy adult premenopausal women is associated negatively with SHBG. Consequently SHBG increased following weight loss in those women. Additionally, the level of SHBG is not affected by insulin. Furthermore, genetic variations of peoples may affect circulating levels of SHBG. Subsequently, the levels of SHBG vary among persons and regions. ${ }^{26} \mathrm{We}$ found that IR was present in obese patients independent of the presence of MetS, but IR present more in the severe category in patients with MetS. In this study, MetS overcomes the effect of IR in decreasing the level of TT among obese men MetS and this finding comparable with the results of a longitudinal study in European men which concluded that TT decrease in men with MetS independent of IR. ${ }^{27}$ However, in our study we found that in obese men with MetS IR does not affect the level of TT and SHBG.

MetS, but not IR had a significant effect in decreasing the levels of TT in obese men, a finding comparable to what was seen in Greece study, which found that MetS itself was responsible for low level of TT in older men. ${ }^{28}$ While both MetS and IR had a significant effect in lowering the level of SHBG in the obese men only versus no effect in obese women patients and this may be attributed to the positive effect of estrogen on SHBG level in adult women during reproductive age. ${ }^{29}$ There was a significant effect of the presence of MetS on low levels of both TT and SHBG in obese men patients' independent of age and IR. These results were the same as the Namwon study ${ }^{30}$ In another study Liao et al., found that only $12.2 \%$ of enrolled subjects met the criteria of MetS in spite of the presence of IR in the most of participants. ${ }^{31}$

\section{Limitation of the study}

The main limitations of this study were small study sample and cross-sectionality.

\section{Conclusion}

In obese men, both low TT and SHBG were independently predict MetS. While in obese women, SHBG was not. The effect of MetS overcomes the effect of IR in decreasing the level of both TT and SHBG among obese men.

\section{Acknowledgements}

None.

\section{Conflicts of interest}

The author declares that there are no conflicts of interest.

\section{Funding}

None.

\section{References}

1. Termizy HM, Mafauzy M. Metabolic syndrome and its characteristics among obese patients attending an obesity clinic. Singapore medical journal. 2009;50(4):390-394.

2. Sherling DH, Perumareddi P, Hennekens CH. Metabolic Syndrome. Journal of cardiovascular pharmacology and therapeutics. 2017;22(4):365-367.

3. Kim MJ, Lim NK, Choi YM, et al. Prevalence of metabolic syndrome is higher among non-obese PCOS women with hyperandrogenism and menstrual irregularity in Korea. PloS one. 2014;9(6):e99252.

4. Lee SC, Hairi NN, Moy FM. Metabolic syndrome among non-obese adults in the teaching profession in Melaka, Malaysia. Journal of epidemiology. 2017;27(3):130-134. 
5. Brand JS, Rovers MM, Yeap BB, et al. Testosterone, sex hormonebinding globulin and the metabolic syndrome in men: an individual participant data meta-analysis of observational studies. PloS one. 2014;9(7):e100409.

6. Isomaa B, Almgren P, Tuomi T, et al. Cardiovascular morbidity and mortality associated with the metabolic syndrome. Diabetes care. 2001;24(4):683-689.

7. Marin P, Holmang S, Gustafsson C, et al. Androgen treatment of abdominally obese men. Obesity research. 1993;1(4):245-251.

8. Jane Ellis M, Livesey JH, Evans MJ. Hormone stability in human whole blood. Clinical biochemistry. 2003;36(2):109-112.

9. Alberti KG, Zimmet P, Shaw J. Metabolic syndrome-a new worldwide definition. A Consensus Statement from the International Diabetes Federation. Diabetic medicine: a journal of the British Diabetic Association. 2006;23(5):469-480.

10. Mather KJ, Hunt AE, Steinberg HO, et al. Repeatability characteristics of simple indices of insulin resistance: implications for research applications. The Journal of clinical endocrinology and metabolism. 2001;86(11):5457-5464.

11. Tanabe M, Akehi Y, Nomiyama T, et al. Total testosterone is the most valuable indicator of metabolic syndrome among various testosterone values in middle-aged Japanese men. Endocrine journal. 2005;62(2):123-132.

12. Hong D, Kim YS, Son ES, et al. Total testosterone and sex hormone-binding globulin are associated with metabolic syndrome independent of age and body mass index in Korean men. Maturitas. 2013;74(2):148-153.

13. Laaksonen DE, Niskanen L, Punnonen K, et al. Testosterone and sex hormone-binding globulin predict the metabolic syndrome and diabetes in middle-aged men. Diabetes care. 2004;27(5):1036-1041.

14. Chughtai B, Lee RK, Te AE, et al. Metabolic syndrome and sexual dysfunction. Curr Opin Urol. 2011;21(6):514-518.

15. Herman AP, Krawczynska A, Bochenek J, et al. LPS-induced inflammation potentiates the IL-1beta-mediated reduction of $\mathrm{LH}$ secretion from the anterior pituitary explants. Clin Dev Immunol. 2013;2013:926937.

16. Bornstein SR, Rutkowski H, Vrezas I. Cytokines and steroidogenesis. Mol Cell Endocrinol. 2004;215(1-2):135-141.

17. Walker BR. Steroid metabolism in metabolic syndrome X. Best practice \& research Clinical endocrinology \& metabolism. 2001;15(1):111-122.

18. Braga-Basaria M, Dobs AS, Muller DC, et al. Metabolic syndrome in men with prostate cancer undergoing long-term androgen-deprivation therapy. Journal of clinical oncology: official journal of the American Society of Clinical Oncology. 2006;24(24):3979-3983.
19. Janssen I, Powell LH, Crawford S, et al. Menopause and the metabolic syndrome: the Study of Women's Health Across the Nation. Arch Intern Med. 2008;168(14):1568-1575.

20. Soriguer F, Rubio-Martin E, Fernandez D, et al. Testosterone, SHBG and risk of type 2 diabetes in the second evaluation of the Pizarra cohort study. European journal of clinical investigation. 2012;42(1):79-85.

21. Haring R, Volzke H, Spielhagen C, et al. The role of sex hormone-binding globulin and testosterone in the risk of incident metabolic syndrome. European journal of preventive cardiology. 2013;20(6):1061-1068.

22. Pang XN, Hu Y, Yuan Y, et al. Lower levels sex hormone-binding globulin independently associated with metabolic syndrome in pre-elderly and elderly men in China. J Geriatr Cardiol JGC. 2013;10(1):28-33.

23. Hautanen A. Synthesis and regulation of sex hormone-binding globulin in obesity. Int J Obes Relat Metab Disord. 2000;24(Suppl 2):S64-S70.

24. Pasquali R, Casimirri F, De Iasio R, et al. Insulin regulates testosterone and sex hormone-binding globulin concentrations in adult normal weight and obese men. The Journal of clinical endocrinology and metabolism. 1995;80(2):654-658.

25. Azrad M, Gower BA, Hunter GR, et al. Intra-abdominal adipose tissue is independently associated with sex-hormone binding globulin in premenopausal women. Obesity. 2012;20(5):1012-1015.

26. Ring HZ, Lessov CN, Reed $\mathrm{T}$, et al. Heritability of plasma sex hormones and hormone binding globulin in adult male twins. The Journal of clinical endocrinology and metabolism. 2005;90(6):3653-3658.

27. Antonio L, Wu FC, O'neill TW, et al. Associations between sex steroids and the development of metabolic syndrome: a longitudinal study in European men. J Clin Endocrinol Metab. 2015;100(4):1396-1404.

28. Chrysohoou C, Panagiotakos D, Pitsavos C, et al. Low total testosterone levels are associated with the metabolic syndrome in elderly men: the role of body weight, lipids, insulin resistance, and inflammation; the Ikaria study. The review of diabetic studies: RDS. 2013;10(1):27-38.

29. Murphy A, Cropp CS, Smith BS, et al. Effect of low-dose oral contraceptive on gonadotropins, androgens, and sex hormone binding globulin in nonhirsute women. Fertility and sterility. 1990;53(1):35-39.

30. Kweon SS, Shin MH, Nam HS, et al. Sex differences in the associations of testosterone and sex hormone-binding globulin with metabolic syndrome in middle-aged and elderly Koreans: the Namwon study. Circulation journal: official journal of the Japanese Circulation Society. 2013;77(3):734-740.

31. Liao Y, Kwon S, Shaughnessy S, et al. Critical evaluation of adult treatment panel III criteria in identifying insulin resistance with dyslipidemia. Diabetes care. 2004;27(4):978-983. 